\title{
UPAYA PENGENALAN WARNA DENGAN MENGGUNAKAN MEDIA PERMAINAN KARTU WARNA PADA ANAK BIMBA AIUEO GRAHA KALIMAS 4 TAMBUN
}

\author{
Reni Junita ${ }^{1}$, Chientya Annisa Rahman Putrie ${ }^{2(*)}$ \\ Universitas Panca Sakti Bekasi, Indonesia ${ }^{12}$ \\ renijunita@gmail.com ${ }^{1}$,Chientya2725@gmail.com²
}

\begin{tabular}{ll}
\hline & \\
Received: & 23 Agustus 2021 \\
Revised: & 23 September 2021 \\
Accepted: & 25 Oktober 2021
\end{tabular}

\begin{abstract}
Usia dini merupakan usia awal yang paling penting dan mendasar sepanjang pertumbuhan dan perkembangan kehidupan manusia. Penelitian ini adalah penelitian tindakan kelas. Aspek-aspek perkembangan tersebut tidak berkembang secara sendiri-sendiri melainkan saling terintegrasi dan saling berhubungan antara perkembangan satu dengan yang lainnya. Dari beberapa aspek perkembangan tersebut, perkembangan kognitif adalah salah satu aspek penting yang harus dikembangkan untuk kemampuan berpikir anak. Salah satunya adalah kemampuan mengenal warna. Namun, pada kenyataannya masih banyak ditemui anak usia 4-5 tahun yang masih kurang mampu mengenal warna. Konsep pokok penelitian tindakan kelas terdiri dari empat komponen, yaitu perencanaan (planning), pelaksanaan (acting), pengamatan atau observasi (observing), dan refleksi (reflecting). Subjek penelitian yang dimaksud dalam penelitian ini adalah guru dan Murid Bimba AIUEO Graha Kalimas 4 Tambun Selatan yang berlokasi di J1. Lapangan Kobra Graha Kalimas 4 Kecamatan Tambun Selatan Kabupaten Bekasi. Penentuan subjek kelas dilakukan saat penelitian mulai memasuki lapangan dan selama penelitian berlangsung. Objek dalam penelitian ini adalah masalah yang ingin di teliti yaitu meningkatkan kemampuan mengenal warna melalui kertas warna di Bimba AIUEO Graha Kalimas 4 Tambun Selatan. Teknik analisis data yang digunakan dalam penelitian ini adalah deskriptif kuantitatif. Hasil menunjukkan bahwa kemampuan mengenal warna pada anak Adanya peningkatan, hal ini dapat dilihat dari peningkatan secara bertahap yaitu rata-rata perolehan persentase pada pra tindakan yaitu 46,43\%, meningkat di Siklus I dengan persentase sebesar $68,75 \%$ dan meningkat mencapai $83,68 \%$ pada Siklus II hingga mencapai target keberhasilan yang diinginkan oleh peneliti yaitu $89.73 \%$.
\end{abstract}

Keywords: Pengenalan Warna, Media Permainan, BIMBA

(*) Corresponding Author: Putrie, chientya2725@gmail.com, +62 81324679391

How to Cite: Junita, R. \& Putrie, C. A. R. (2021). Upaya Pengenalan Warna Dengan Menggunakan Media Permainan Kartu Warna Pada Anak Bimba AIUEO Graha Kalimas 4 Tambun. Research and Development Journal of Education, 7 (2), 525-531.

\section{INTRODUCTION}

Usia dini merupakan usia awal yang paling penting dan mendasar sepanjang pertumbuhan dan perkembangan kehidupan manusia. Pada usia ini, memberikan pendidikan sejak dini sangat penting untuk perkembangan kemampuan anak. Penelitian membuktikan memberikan pendidikan anak sejak dini sangat baik karena pendidikan usia dini merupakan dasar untuk tahap tumbuh kembang anak selanjutnya. Masa pertumbuhan dan perkembangan anak usia dini harus dipantau secara terus menerus sehingga akan cepat diketahui kematangan dan kesiapannya, baik yang menyangkut perkembangan 
kemampuan dasar seperti kognitif, bahasa, dan motorik maupun perkembangan kemampuan lainnya yang akan membentuk karakter mereka kelak.

Aspek-aspek perkembangan tersebut tidak berkembang secara sendiri-sendiri melainkan saling terintegrasi dan saling berhubungan antara perkembangan satu dengan yang lainnya. Dari beberapa aspek perkembangan tersebut, perkembangan kognitif adalah salah satu aspek penting yang harus dikembangkan untuk kemampuan berpikir anak. Hal ini agar anak dapat mengelola perolehan belajarnya, memecahkan masalah, membantu anak untuk mengembangkan kemampuan logika matematika dan pengetahuan akan ruang dan waktu, serta mempersiapkan pengembangan kemampuan berpikir teliti (Kriswidyantari, Sujana, dan Wiyasa, 2016). Senada dengan pendapat sebelumnya, Karim dan Wifroh (2014) mengatakan bahwa proses kognisi meliputi berbagai aspek seperti persepsi, ingatan, pikiran, simbol, penalaran, dan pemecahan masalah. Dengan demikian perkembangan kognitif merupakan aspek yang sangat penting untuk dikembangkan karena melalui perkembangan kognitif anak dapat memperoleh kemampuan dalam berpikir, memecahkan masalah dan mengembangkan kemampuan logika dalam perkembangan anak selanjutnya.

Kemampuan mengenal warna merupakan salah satu aspek dari kemampuan kognitif. Kemampuan mengenal warna pada anak usia dini merupakan hal yang sangat penting bagi perkembangan otaknya, sebab pengenalan warna pada anak usia dini dapat merangsang indera penglihatan otak. Warna juga dapat memancing kepekaan terhadap penglihatan yang terjadi karena warna yang ada pada benda terkena sinar matahari baik secara langsung atau tidak langsung yang kemudian dapat dilihat oleh mata. Seperti pendapat Fudyartanta (2011:195) bahwa proses pengindraan mata terjadi melalui fasefase sebagai berikut: a) Saat fase fisis jalannnya perangsang dari benda sampai pada mata, artinya pada saat cahaya sampai pada kornea mata, diteruskan melalui lensa mata sampai pada bintik kuning pada retina; b) Fase psikis yaitu jalannya perangsangan di dalam badan, prosesnya saat mata melihat benda (warna benda) diteruskan ke urat saraf mata dan kemudia sampai ke otak (pusat penglihatan) dan; c) psikis yaitu jalannya terjadinya penginderaan atau pengetahuan tentang objek, dalam hal melihat objeknya adalah warna benda, disini tidak ada perangsangan lagi, hanya kesadaran bahwa kita melihat warna benda tersebut. Saat psikis inilah reaksi jiwa dengan alat indranya atas penusukan otak oleh perangsangnya. Selain dapat merangsang indera penglihatan, pengenalan warna juga meningkatkan kreativitas anak dan daya pikir yang berpengaruh pada perkembangan intelektual yakni kemampuan mengingat. Oleh sebab itu, mengenalkan warna sejak usia dini khususnya usia 4-5 tahun sangat dianjurkan agar anak dapat membedakan dan mengetahui macam-macam warna dasar dan komplemennya.

Peraturan Menteri tahun 2009 Nomor 58 menyatakan bahwa ruang lingkup yang harus dikuasai dalam kemampuan kognitif anak khususnya anak usia 4-5 tahun salah satunya adalah mengenal konsep warna. Tingkat pencapaian perkembangan pengenalan warna anak usia 4-5 tahun antara lain: (1) mengklasifikasikan benda berdasarkan warna; (2) mengklasifikasikan benda kedalam kelompok (warna) yang sama, (warna) sejenis atau kelompok yang berpasangan dengan 2 variasi; (3) mengenal pola (warna) $\mathrm{AB}-\mathrm{AB}$ dan $\mathrm{ABC}-\mathrm{ABC}$; dan (4) mengurutkan benda berdasarkan 5 seriasi warna. Peraturan Menteri tersebut dapat disimpulkan bahwa kemampuan kognitif mengenal warna anak usia 4-5 tahun harus dapat mencakup kelima hal tersebut, yang bertujuan agar anak mampu mengetahui pengetahuan umum dan sains, konsep warna, ukuran, bentuk dan pola, konsep bilangan, lambang bilangan dan huruf.

Peran guru di sini dalam menstimulasi anak mengenalkan warna sangat dibutuhkan. Pengenalan warna dapat dilakukan guru dengan memilih kegiatan menarik, sederhana, menyenangkan bagi anak, dan tentunya dapat mengembangkan keterampilan kognitif anak dalam mengenal warna. Melatih anak melalui kegiatan dan menggunakan 
berbagai media tersebut dapat menstimulasi kemampuan mengenal warna baik kemampuan menunjuk, menyebut, dan mengelompokkan warna dasar dan komplimennya. Namun, pada kenyataannya masih banyak ditemui anak usia 4-5 tahun yang masih kurang mampu mengenal warna.

Saat kegiatan pembelajaran anak masih ragu-ragu dan tidak mau melakukan perintah guru, yaitu anak tidak mau menunjuk, menyebut, dan mengelompokkan warna sehingga masih harus dibujuk dan dibantu guru. Anak dalam pada kemampuan menunjuk warna masih ragu-ragu dan berganti-ganti, seperti saat guru meminta anak menunjuk warna kuning, anak masih menunjukkan 2 warna yang berbeda yaitu warna kuning kemudian berganti menunjuk warna oranye. Pada kemampuan menyebutkan warna, anak belum bisa membedakan warna merah dengan orange, kuning dengan oranye, hijau dengan biru, biru dengan ungu dan sebagainya. Selain itu, beberapa anak dalam mengelompokkan warna merah masih belum tepat yang seharusnya mengelompokkan 3 warna merah, mengambil 2 merah 1 orange, yang seharusnya mengambil 3 warna hijau mengambil 1 warna hijau 1 warna kuning dan 1 warna biru.

Begitu juga hal yang dialami oleh penulis dalam beberapa aktivitas kelas, di BIMBA AIUEO kemampuan mengenal warna anak masih belum optimal. Hal ini terlihat dari banyaknya anak yang belum bisa membedakan warna yaitu sebanyak 10 anak atau kurang dari $70 \%$ dari jumlah anak didik sebanyak 14 anak yang belum memahami warna, yaitu masih keliru membedakan antara warna merah dengan oranye, serta warna biru dengan hijau.

Berdasarkan permasalahan yang dipaparkan di atas, melalui pendekatan Penelitian Tindakan Kelas (PTK), maka peneliti ingin mengetahui perkembangan anak usia 4-5 tahun dalam kemampuan mengenal warna di Bimba AIUEO Graha Kalimas 4 Tambun, Kecamatan Tambun Selatan Kabupaten Bekasi. Oleh karena itu, dalam penelitian ini penulis merumuskan judul "Upaya Pengenalan Warna Dengan Menggunakan Media Permainan Kartu Warna Pada Anak Bimba AIUEO Graha Kalimas 4 Tambun”.

\section{METHODS}

Penelitian ini adalah penelitian tindakan kelas. Konsep pokok penelitian tindakan kelas terdiri dari empat komponen, yaitu perencanaan (planning), pelaksanaan (acting), pengamatan atau observasi (observing), dan refleksi (reflecting). Hubungan keempat komponen tersebut dipandang sebagai siklus yang dapat digambarkan dalam bentuk dibawah ini. 


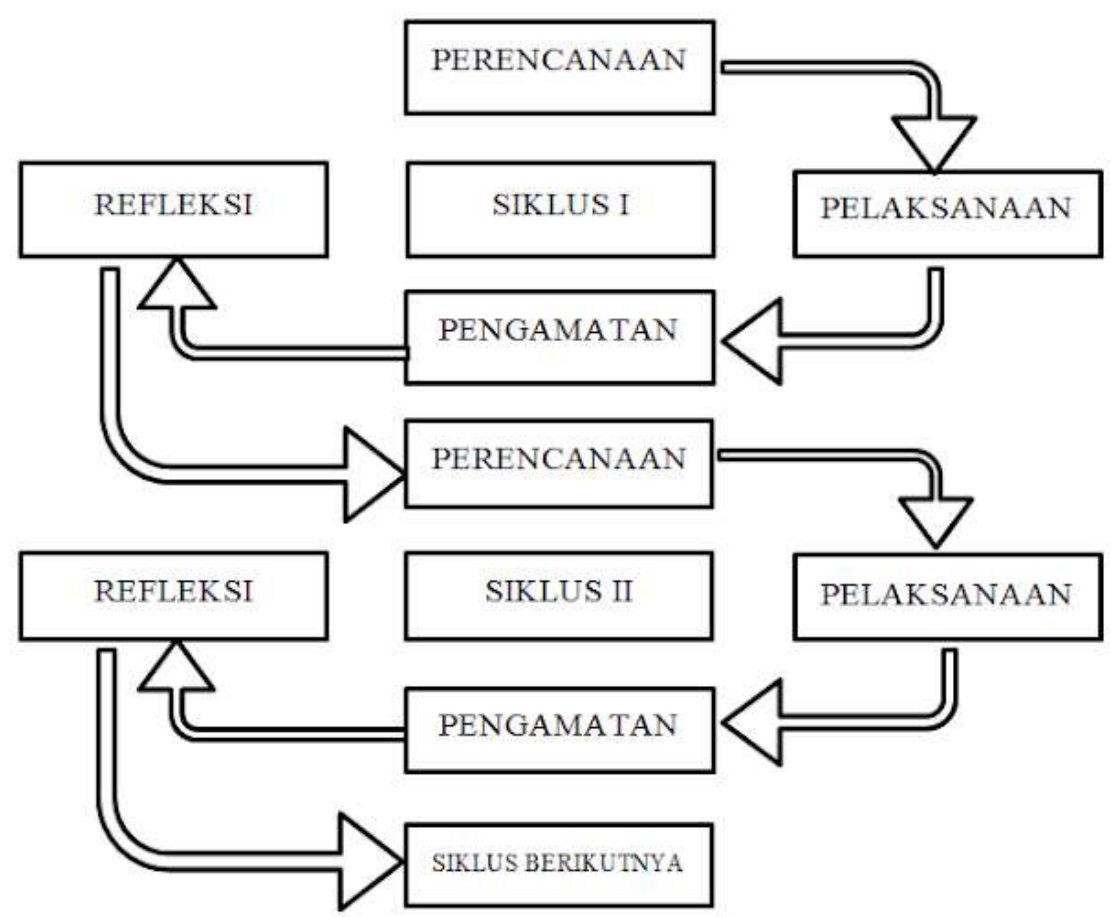

Gambar 1.

Siklus Penelitian Tindakan Kelas Model Kurt Lewin Sumber: Peneliti (2021)

Subjek penelitian yang dimaksud dalam penelitian ini adalah guru dan Murid Bimba AIUEO Graha Kalimas 4 Tambun Selatan yang berlokasi di Jl. Lapangan Kobra Graha Kalimas 4 Kecamatan Tambun Selatan Kabupaten Bekasi. Penentuan subjek kelas dilakukan saat penelitian mulai memasuki lapangan dan selama penelitian berlangsung. Objek dalam penelitian ini adalah masalah yang ingin di teliti yaitu meningkatkan kemampuan mengenal warna melalui kertas warna di Bimba AIUEO Graha Kalimas 4 Tambun Selatan. Teknik analisis data yang digunakan dalam penelitian ini adalah deskriptif kuantitatif.

\section{RESULTS \& DISCUSSION}

Pelaksanaan pra tindakan ini dilakukan untuk mengetahui kemampuan awal anak dalam mengenal warna sebelum diberikan tindakan. Pihak yang melaksanakan kegiatan pembelajaran adalah guru, sedangkan yang melakukan pengamatan adalah peneliti yang dibantu oleh teman sejawat. Pelaksanaan kegiatan pra tindakan berupa kegiatan pembelajaran dengan memberi warna bentuk geometri dengan warna-warna primer biru, merah, dan kuning, kemudian membuat warna baru yaitu warna orange, hijau, dan ungu. Kegiatan mengenalkan warna pada pratindakan dilakukan dengan media kertas warna. Kegiatan pratindakan menggunakan teknik pengumpulan data observasi dan dokumentasi, pengamatan terhadap kemampuan menyebutkan warna, mengelompokkan warna.

Hasil kemampuan mengenal warna pada pratindakan ini menunjukkan bahwa kemampuan mengenal warna masih rendah. Hal ini pene;iti sajikan dalam dapat Tabel 1 berikut. 
Tabel 1.

Hasil Observasi Pra tindakan Kemampuan Mengenal Warna

\begin{tabular}{llcccc}
\hline Sub Variabel & \multicolumn{1}{c}{ Indikator } & $\begin{array}{c}\text { Skor } \\
\text { Keseluruhan }\end{array}$ & \% Skor & $\begin{array}{c}\text { Rata-rata } \\
\text { \% Skor }\end{array}$ & Kiteria \\
\hline $\begin{array}{l}\text { Mengenal } \\
\text { warna }\end{array}$ & $\begin{array}{l}\text { Anak dapat } \\
\text { menyebutkan Warna }\end{array}$ & 27 & $48.21 \%$ & & Mulai \\
$\begin{array}{l}\text { Menggolongk } \\
\text { an warna }\end{array}$ & $\begin{array}{l}\text { Anak mampu } \\
\text { mengelompok-kan } \\
\text { waran }\end{array}$ & 25 & $44.64 \%$ & $46.43 \%$ & Berkembang \\
\hline
\end{tabular}

Sumber: Peneliti (2021)

Berdasarkan tabel di atas, dapat diketahui bahwa hasil dari kegiatan pra tindakan kemampuan mengenal warna pada siswa di Bimba AIUEO Graha Kalimas 4 Tambun Selatan masih rendah. Hasil observasi kemampuan mengenal warna pada pra tindakan adalah $46.43 \%$ yang tergolong dalam kriteria cukup. Dari hasil tersebut menunjukkan bahwa perlu upaya peningkatan kemampuan mengenal warna agar tercapai kriteria keberhasilan yaitu lebih dari $80 \%$.

Kemampuan mengenal warna merupakan salah satu aspek penting bagi anak. Mengenal simbol warna akan memberikan bekal bagi anak untuk mengenal lingkungan sekitarnya. Penelitian ini merupakan jenis penelitian tindakan kelas dengan 2 siklus dan setiap siklusnya terdiri dari 3 kali pertemuan. Berdasarkan observasi pada pratindakan, kemampuan mengenal warna pada anak siswa di Bimba AIUEO Graha Kalimas 4 Tambun Selatan masih dalam kategori belum mampu. Pada saat pembelajaran lebih sering terjadi secara satu arah, yaitu guru yang lebih dominan dan keterlibatan anak masih kurang. Pembelajaran mengenal warna pada anak, guru lebih cenderung memberikan nama-nama warna dan menunjukkan warna. Untuk itu, dengan diterapkannya penggunaan media kertas warna pada pembelajaran diharapkan dapat meningkatkan kemampuan anak dalam mengenal warna.

Berdasarkan hasil observasi pada pratindakan menunjukkan bahwa kemampuan mengenal warna pada anak masih dalam kategori belum mampu. Sebagian besar anak dalam hal menyebutkan warna masih distimulasi oleh guru, masih ditemukan pula anak yang belum mampu mengelompokkan warna. Dalam menyebutkan dan mengelompokkan warna primer, anak juga masih ragu-ragu. Hal ini belum sesuai dengan tingkat pencapaian perkembangan anak usia dini yang terdapat dalam Permendiknas Nomor 58 Tahun 2009 tentang kemampuan anak dalam mengenal warna yaitu mampu menyebutkan 5-7 warna dan mampu mengelompokkan warna.

Berdasarkan hal tersebut, kemampuan mengenal warna pada anak masih perlu ditingkatkan, yaitu dengan pembelajaran yang menyenangkan menggunakan media dan melibatkan anak supaya anak dapat memahami setiap pembelajaran yang diperolehnya. Penggunaan metode pembelajaran yang tepat disesuaikan dengan karakteristik anak. Hal ini sesuai dengan pendapat Khasanah dan Hani'ah (2018) yang menyatakan bahwa pemilihan metode pembelajaran juga memperhatikan karakteristik anak bahwa anak pada umumnya adalah anak yang selalu bergerak, mempunyai rasa ingin tahu yang kuat, senang bereksperimen dan menguji, mampu mengekspresikan dari secara kreatif, mempunyai imajinasi, dan senang berbicara.

Media pembelajaran adalah adalah alat yang dapat membantu proses belajar mengajar sehingga makna pesan yang disampaikan menjadi lebih jelas dan tujuan pendidikan atau pembelajaran dapat tercapai dengan efektif dan efisien. Hasil belajar adalah hasil yang diberikan kepada siswa berupa penilaian setelah mengikuti proses pembelajaran dengan menilai pengetahuan, sikap, ketrampilan pada diri siswa dengan adanya perubahan tingkah laku. Media pembelajaran berfungsi sebagai salah satu sumber belajar bagi siswa untuk memperoleh pesan dan informasi yang berikan oleh guru 
sehingga materi pembelajaran dapat lebih meningkat dan membentuk pengetahuan bagi siswa. Penggunaan media pada kegiatan mengenalkan warna akan memberikan pengalaman langsung kepada anak untuk melakukan (doing) sehingga pembelajaran yang dilakukan tidak hanya menghafal namun juga akan lebih bermakna bagi anak. Selain itu, dalam menggunakan media bahan-bahan dan alat yang digunakan bersifat konkrit dan anak memperoleh pengalaman langsung dalam kegiatan pembelajaran. Pengalaman belajar siswa akan meningkat atau berkontribusi besar bagi pengetahuan anak apabila diperoleh melalui proses perbuatan atau mengalami langsung apa yang dipelajarinya (Pratiwi, 2017). Kegiatan melakukan eksperimen merupakan kegiatan yang menarik bagi anak. Pada penelitian ini percobaan yang dilakukan adalah dengan bermain warna.

Pada Siklus I diperoleh hasil observasi bahwa kemampuan anak dalam mengenal warna telah mengalami peningkatan namun belum optimal. Beberapa anak masih malumalu untuk melakukan kegiatan. Serta, setting tempat duduk yang dibuat tidak mengelompok menyebabkan anak susah untuk saling berbagi dengan temannya. Kendala pada Siklus I dapat diatasi pada Siklus II. Anak sudah terbiasa melakukan kegiatan pembelajaran sehingga tidak malu lagi dan tertarik dengan macam-macam kegiatan dalam pengenalan warna, selain itu setting tempat duduk anak juga dibuat menjadi 3 kelompok. Kemampuan mengenal warna pada anak menunjukkan peningkatan, hal ini dapat dilihat dari peningkatan secara bertahap yaitu rata-rata perolehan persentase pada pra tindakan yaitu 46,43\%, meningkat di Siklus I dengan persentase sebesar 68,75\% dan meningkat mencapai $83,68 \%$ pada Siklus II hingga mencapai target keberhasilan yang diinginkan oleh peneliti yaitu $89.73 \%$.

Berdasarkan penelitian yang dilakukan pada anak usia dini tahun di Bimba AIUEO Graha Kalimas 4 Tambun Selatan menunjukkan bahwa kegiatan pembelajaran mengenal warna dapat meningkat dengan menggunakan media kertas warna. Hal ini dapat dilihat dari data yang diperoleh pada pratindakan, Siklus I, dan Siklus II yang mengalami peningkatan secara bertahap.

\section{CONCLUSION}

Berdasarkan penelitian tindakan kelas yang bersifat kolaboratif antara peneliti dengan guru kelas dapat disimpulkan bahwa adanya peningkatan kemampuan mengenal warna dengan menggunakan media kertas warna pada siswa di Bimba AIUEO Graha Kalimas 4 Tambun Selatan. Peningkatan kemampuan mengenal warna pada anak dapat dilihat dari hasil observasi pada pratindakan, Siklus I dan Siklus II. Meningkatnya kemampuan mengenal warna pada anak siswa melalui media kertas warna dilakukan dengan memberi kesempatan kepada anak dalam mengelompokkan warna. Langkahlangkah pembelajaran yang ditempuh sehingga terjadi peningkatan terhadap pada kemampuan mengenal warna diantaranya guru mempersiapkan media kertas warna yang akan digunakan dalam kegiatan pembelajaran, selanjutnya guru menjelaskan materi dan mendemonstrasikan kepada siswa. Kemudian anak melakukan kegiatan menyebutkan, mengelompokkan, melipat kertas warna, dan diberikan tugas untuk menyebutkan 5-7 macam warna, menyampaikan hasil kegiatan melipat yang telah dilakukan anak, dan mengelompokkan warna. Data yang diperoleh menunjukkan adanya peningkatan terhadap kemampuan mengenal warna yang dapat mencapai indikator keberhasilan yaitu perolehan rata-rata persentase lebih dari $86.70 \%$. Pada pratindakan memperoleh persentase $46,43 \%$ yang termasuk dalam kriteria cukup, meningkat menjadi $68,75 \%$ pada Siklus I yang termasuk dalam kriteria baik, dan menjadi $89.73 \%$ yang termasuk dalam kriteria sangat baik pada Siklus II 


\section{REFERENCES}

Fudyartanta, Ki. (2011). Psikologi Umum. Yogyakarta: Pustaka pelajar.

Karim, M. B., \& Wifroh, S. H. (2014). Meningkatkan Perkembangan Kognitif pada Anak Usia Dini Melalui Alat Permainan Edukatif. Jurnal PG-PAUD Trunojoyo: Jurnal Pendidikan dan Pembelajaran Anak Usia Dini, 1(2), 103-113.

Khasanah, N. F., \& Hani'ah, N. (2018). Strategi Peningkatan Kemampuan Anak Usia Dini dalam Mengenal Warna melalui Metode Eksperimen. Atthiflah: Journal of Early Childhood Islamic Education, 5(2), 22-34.

Kriswidyantari, N. M., Sujana, I. W., \& Wiyasa, I. K. N. (2016). Penerapan Permainan Sains Untuk Meningkatkan Kemampuan Berpikir Kritis Anak Kelompok A1 TK Negeri Pembina Denpasar. Jurnal Pendidikan Anak Usia Dini Undiksha, 4(2).

Pratiwi, N. K. (2017). Pengaruh tingkat pendidikan, perhatian orang tua, dan minat belajar siswa terhadap prestasi belajar bahasa indonesia siswa smk kesehatan di kota tangerang. Pujangga, 1(2), 31. 